\title{
Bowmanella pacifica sp. nov., isolated from a pyrene-degrading consortium
}

\author{
Qiliang Lai, ${ }^{1} \dagger$ Jun Yuan, ${ }^{1}{ }^{2}+$ Baojiang Wang, ${ }^{1}$ Fengqin Sun, ${ }^{1}$ Nan Qiao, ${ }^{1}$ \\ Tianling Zheng ${ }^{2}$ and Zongze Shao ${ }^{1}$
}

Correspondence

Zongze Shao shaozz@163.com

Tianling Zheng

wshwzh@jingxian.xmu.edu.cn

\author{
${ }^{1}$ Key Laboratory of Marine Biogenetic Resources, Third Institute of Oceanography, State Oceanic \\ Administration, Xiamen 361005, PR China \\ ${ }^{2} \mathrm{MOE}$ of Key Lab for Coast and Wetland Ecosystem, School of Life Sciences, Xiamen University, \\ Xiamen 361005, PR China
}

\begin{abstract}
A taxonomic study was carried out on a strain, designated $\mathrm{W} 3-3 \mathrm{~A}^{\top}$, which was isolated from a pyrene-degrading consortium, enriched from sediment of the Pacific Ocean. Phylogenetic analysis based on 16S rRNA gene sequences indicated that strain $\mathrm{W} 3-3 \mathrm{~A}^{\top}$ belonged to the genus Bowmanella, with the highest sequence similarity $(99.0 \%)$ with Bowmanella denitrificans $B D 1^{\top}$, whereas sequence similarities with other species were less than $93 \%$. The nucleotide sequence similarity of both $g y r B$ and $r p o D$ genes of strain $\mathrm{W} 3-3 A^{\top}$ and $B$. denitrificans $B D 1^{\top}$ was $81.1 \%$. However, the protein sequence similarities of the gyrB and $r p o D$ genes of strain $W 3-3 A^{\top}$ and $B$. denitrificans $\mathrm{BD}^{\top}{ }^{\top}$ were $96.1 \%$ and $91.0 \%$, respectively. Phylogenetic trees based on these housekeeping genes showed that strain $\mathrm{W} 3-3 A^{\top}$ and $B$. denitrificans $B D 1^{\top}$ formed a distinct lineage in the Gammaproteobacteria. The DNA-DNA hybridization value between strain W3-3A $A^{\top}$ and $B$. denitrificans $B D 1^{\top}$ was $43 \%$. Strain W3-3A ${ }^{\top}$ could also be differentiated from $B$. denitrificans $B D 1^{\top}$ based on the repetitive extragenic palindromic DNA-PCR fingerprint. The $G+C$ content of the chromosomal DNA of strain $W 3-3 A^{\top}$ was $49 \mathrm{~mol} \%$. The combined genotypic and phenotypic data showed that strain $\mathrm{W} 3-3 \mathrm{~A}^{\top}$ represents a novel species of the genus Bowmanella, for which the name Bowmanella pacifica sp. nov. is proposed, with the type strain W3-3A $A^{\top}\left(=\right.$ CGMCC $1.7086^{\top}=$ LMG $24568^{\top}=$ MCCC $\left.1 \mathrm{~A}^{\top} 1018^{\top}\right)$.
\end{abstract}

During the screening of pyrene-degrading bacteria, an Alteromonas-like bacterium, designated strain $\mathrm{W} 3-3 \mathrm{~A}^{\mathrm{T}}$, was isolated from a pyrene-degrading consortium, enriched from sediment of the Pacific Ocean in 2002 (Wang et al., 2008), and was selected for further characterization by using a polyphasic approach, including genotypic, chemo-

†These authors contributed equally to this work.

Abbreviations: gyrB, DNA gyrase subunit B gene; $r p o D$, DNA-directed RNA polymerase subunit $D$ gene; rep-PCR, repetitive extragenic palindromic DNA-PCR.

The GenBank/EMBL/DDBJ accession numbers for the nucleotide sequences reported in this study are EU440951 (Bowmanella pacifica W3-3A ${ }^{\top}, 16 S$ rRNA gene), EU441038 (B. pacifica W3-3A', partial gyrB gene), EU441040 (B. pacifica W3-3A', partial rpoD gene), EU441037 (Bowmanella denitrificans $\mathrm{BD}^{\top}{ }^{\top}$, partial gyrB gene) and EU441039 (B. denitrificans $\mathrm{BD} 1^{\top}$, partial rpoD gene).

Transmission electron micrographs of cells of strain $W_{3}-3 A^{\top}$, dendrograms showing the phylogenetic positions of strain $W 3-3 A^{\top}$ and related species based on gyr $B$ and $r p o D$ gene sequences, and results of rep$\mathrm{PCR}$ and polar lipid analysis of strain $\mathrm{W} 3-3 \mathrm{~A}^{\top}$ and $B$. denitrificans $B D 1^{\top}$ and a table showing the cellular fatty acid contents of strain $\mathrm{W} 3-3 \mathrm{~A}^{\top}$ and $B$. denitrificans $\mathrm{BD} 1^{\top}$ are available as supplementary material with the online version of this paper. taxonomic and classical phenotypic characteristics. Based on these results, we consider that strain $\mathrm{W} 3-3 \mathrm{~A}^{\mathrm{T}}$ should be classified as representing a novel species of the genus Bowmanella, which was proposed by Jean et al. (2006). Strains isolated in this study were stored at $-80{ }^{\circ} \mathrm{C}$ in M2 medium ( $1^{-1}$ seawater: $\mathrm{CH}_{3} \mathrm{COONa}, 5.0 \mathrm{~g}$; tryptone, $0.5 \mathrm{~g}$; yeast extract, $0.5 \mathrm{~g}$; glucose, $0.5 \mathrm{~g}$; sucrose, $0.5 \mathrm{~g}$; sodium citrate, $0.05 \mathrm{~g}$; malic acid, $0.05 \mathrm{~g}$; $\mathrm{NH}_{4} \mathrm{NO}_{3}, 1.0 \mathrm{~g} ; \mathrm{NH}_{4} \mathrm{Cl}$, $0.2 \mathrm{~g} ; \mathrm{KH}_{2} \mathrm{PO}_{4}, 0.5 \mathrm{~g}$; adjusted to $\mathrm{pH}$ 7.6) (Wang et al., 2008), supplemented with $16 \%$ (v/v) glycerol for maintenance. M2 medium was used for routine cultivation of the isolates and most phenotypic tests. All cultures were incubated at $28{ }^{\circ} \mathrm{C}$ unless noted otherwise.

Genomic DNA was prepared according to the method of Ausubel et al. (1995) and the 16S rRNA gene was amplified by PCR using primers that have been described previously (Liu \& Shao, 2005). Sequences of related taxa were obtained from the GenBank database. Phylogenetic analysis was performed using MEGA version 4 (Tamura et al., 2007) after multiple alignments of data by using DNAMAN (version 5.1; Lynnon Biosoft). Distances (distance options according to the Kimura two-parameter model) and clustering with the neighbour-joining method of Saitou \& Nei (1987) 
and minimum-evolution methods of Rzhetsky \& Nei $(1992,1993)$ were determined by using bootstrap values based on 1000 replications. As the topology of the minimum-evolution tree was similar to that obtained using the neighbour-joining method, the data generated using minimum-evolution are not shown.

A nearly full-length $16 \mathrm{~S}$ rRNA gene sequence (1496 nt) of strain $\mathrm{W} 3-3 \mathrm{~A}^{\mathrm{T}}$ was determined. As shown in Fig. 1, the phylogenetic tree based on 16S rRNA gene sequences showed that strain $\mathrm{W} 3-3 \mathrm{~A}^{\mathrm{T}}$ and Bowmanella denitrificans $\mathrm{BD} 1^{\mathrm{T}}$ formed an independent monophyletic cluster, with a high level of similarity $(99.0 \%)$; similarity values between the sequence of strain $\mathrm{W} 3-3 \mathrm{~A}^{\mathrm{T}}$ and those of other related taxa were all less than $93 \%$. The high level of $16 \mathrm{~S}$ rRNA gene similarity confirmed that strain $\mathrm{W} 3-3 \mathrm{~A}^{\mathrm{T}}$ belonged to the genus Bowmanella.

For further comparison of strain $\mathrm{W} 3-3 \mathrm{~A}^{\mathrm{T}}$ with $B$. denitrificans $\mathrm{BD}^{\mathrm{T}}$, two housekeeping genes, the DNA gyrase subunit B gene $(g y r B)$ and the DNA-directed RNA polymerase subunit $\mathrm{D}$ gene $(r p o D)$ of the two strains were sequenced using the method described by Yamamoto et al. (2000). The similarity values between the gyrB and $r p o D$ gene sequences of strain $\mathrm{W} 3-3 \mathrm{~A}^{\mathrm{T}}$ and $B$. denitrificans $\mathrm{BD} 1^{\mathrm{T}}$ were both $81.1 \%$. In addition, the protein sequence similarities of the gyrB and $r p o D$ genes of strain W3-3A $\mathrm{A}^{\mathrm{T}}$ and $B$. denitrificans $\mathrm{BD}^{\mathrm{T}}$ were 96.1 and $91.0 \%$, respectively. As shown in Supplementary Figs S1 and S2 (available in IJSEM Online), phylogenetic trees based on the sequences of the two housekeeping genes showed that strain $\mathrm{W} 3-3 \mathrm{~A}^{\mathrm{T}}$ and $B$. denitrificans $\mathrm{BD}^{\mathrm{T}}$ formed an independent monophyletic cluster, similar to that obtained based on the 16S rRNA gene sequences. Strain W3-3A ${ }^{\mathrm{T}}$ could be differentiated from $B$. denitrificans $\mathrm{BD}^{\mathrm{T}}$ based on these results.

DNA-DNA hybridization experiments were performed with genomic DNA of strain $\mathrm{W} 3-3 \mathrm{~A}^{\mathrm{T}}$ and $B$. denitrificans $\mathrm{BD} 1^{\mathrm{T}}$ using a method that was described previously (Liu \& Shao, 2005). Genomic DNA from Escherichia coli DH5 $\alpha$ was used as an outgroup sample. Salmon sperm DNA was used as a negative control. The results showed that strain
W3-3A $\mathrm{A}^{\mathrm{T}}$ and $B$. denitrificans $\mathrm{BD}^{\mathrm{T}}$ had low DNA-DNA relatedness $(43 \%)$, demonstrating their affiliation to different species in accordance with the cut-off value of $70 \%$ recognized by Wayne et al. (1987) for discrimination of bacterial species. Strain $\mathrm{W} 3-3 \mathrm{~A}^{\mathrm{T}}$ and $B$. denitrificans $\mathrm{BD} 1^{\mathrm{T}}$ were compared further by using repetitive extragenic palindromic DNA-PCR fingerprint (rep-PCR). The primer BOX-A1R (5'-CTACGGCAAGGCGACGCTGACG-3') was used for rep-PCR fingerprint analysis (Versalovic et al. 1991). PCR was carried out with the following cycle conditions: denaturation for $5 \mathrm{~min}$ at $94{ }^{\circ} \mathrm{C} ; 35$ cycles of $15 \mathrm{~s}$ at $94{ }^{\circ} \mathrm{C}, 30 \mathrm{~s}$ at $53{ }^{\circ} \mathrm{C}$ and $8 \mathrm{~min}$ at $65^{\circ} \mathrm{C}$ and a final extension at $65{ }^{\circ} \mathrm{C}$ for $8 \mathrm{~min}$. The PCR products were separated by using agarose $(2 \%, \mathrm{w} / \mathrm{v})$ gel electrophoresis. The rep-PCR result is shown in Supplementary Fig. S3 (in IJSEM Online). Strain $\mathrm{W} 3-3 \mathrm{~A}^{\mathrm{T}}$ showed a rep-PCR fingerprint pattern that was different from that of $B$. denitrificans $\mathrm{BD}^{\mathrm{T}}$. These results further confirmed the results of the DNA-DNA hybridization.

General cell morphology was studied under an Olympus inverted microscope (Olympus IX70) using 1 day-old cultures of strain $\mathrm{W} 3-3 \mathrm{~A}^{\mathrm{T}}$ grown on M2 agar medium. For electron microscopy, exponential-phase cells were harvested, suspended and absorbed on a Formvarcarbon-coated grid, and stained with phosphotungstic acid. The Gram reaction and catalase and oxidase activities were carried out according to Dong \& Cai (2001). The optimal temperature for growth (using 4, 10,20,25, 37, 42 and $55{ }^{\circ} \mathrm{C}$ ) and $\mathrm{pH}$ (from $\mathrm{pH} 3$ to 12 ) were determined in M2 medium. Tolerance of $\mathrm{NaCl}$ was tested by using LuriaBertani (LB) medium ( $10 \mathrm{~g}$ peptone $\mathrm{l}^{-1}$ and $5 \mathrm{~g}$ yeast $\mathrm{l}^{-1}$ ), supplemented with $\mathrm{NaCl}$ concentrations of $0,0.5,1,3,5,7$, $8,9,10,12$ and $15 \%(\mathrm{w} / \mathrm{v})$. Other biochemical tests were carried out in duplicate using API 20NE and API ZYM strips (bioMérieux) and the Biolog GN2 MicroPlate panel, according to the manufacturers' instructions, with the adjustment that the $\mathrm{NaCl}$ concentration was $3.0 \%$. With the exception of the Biolog test, $B$. denitrificans $\mathrm{BD}^{\mathrm{T}}$ was tested at the same time as strain $\mathrm{W} 3-3 \mathrm{~A}^{\mathrm{T}}$ for comparison.

Strain $\mathrm{W} 3-3 \mathrm{~A}^{\mathrm{T}}$ was found to be a Gram-negative, nonpigmented, rod-shaped bacterium that was motile by

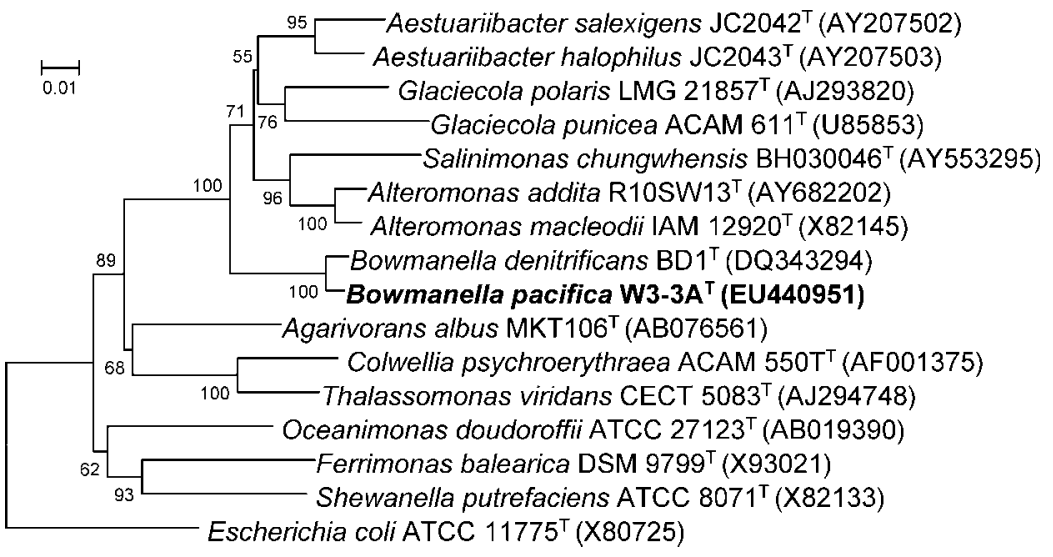

Fig. 1. Neighbour-joining tree showing the phylogenetic positions of strain $\mathrm{W} 3-3 \mathrm{~A}^{\mathrm{T}}$ and representatives of some other related taxa, based on 16S rRNA gene sequences. Bootstrap values (expressed as percentages of 1000 replications) are shown at branch points. Bar, 0.01 nucleotide substitution rate $\left(K_{\text {nuc }}\right)$ units. 
means of at least one polar flagellum (see Supplementary Fig. S4 in IJSEM Online). The differential physiological, biochemical and chemotaxonomic characteristics between strain $\mathrm{W} 3-3 \mathrm{~A}^{\mathrm{T}}$ and $B$. denitrificans $\mathrm{BD} 1^{\mathrm{T}}$ are given in Table 1.

Antibiotic susceptibility tests were performed by using disc-diffusion methods as described by Shieh et al. (2003). Strain $\mathrm{W} 3-3 \mathrm{~A}^{\mathrm{T}}$ and $B$. denitrificans $\mathrm{BD} 1^{\mathrm{T}}$ were tested at the same time in this study. The two strains were sensitive to chloramphenicol (30 $\mu \mathrm{g}$ per disk; Oxoid), ciprofloxacin $(5 \mu \mathrm{g})$, co-trimoxazole $(25 \mu \mathrm{g})$, erythromycin $(15 \mu \mathrm{g})$, rifampicin $(5 \mu \mathrm{g})$, gentamicin $(10 \mu \mathrm{g})$, norfloxacin $(10 \mu \mathrm{g})$ and polymyxin $\mathrm{B}(30 \mathrm{IU})$; and resistant to ampicillin $(10 \mu \mathrm{g})$, carbenicillin $(100 \mu \mathrm{g})$, cefalexin $(30 \mu \mathrm{g})$, cefazolin $(30 \mu \mathrm{g})$, cefoperazone $(30 \mu \mathrm{g})$, cephradin $(30 \mu \mathrm{g})$, clindamycin $(2 \mu \mathrm{g})$, lincomycin $(2 \mu \mathrm{g})$, metronidazole $(5 \mu \mathrm{g})$, minocycline $(30 \mu \mathrm{g})$, oxacillin $(1 \mu \mathrm{g})$, penicillin $\mathrm{G}(10 \mu \mathrm{g})$, ceftriaxone $(30 \mu \mathrm{g})$, tetracycline $(30 \mu \mathrm{g})$ and doxycycline $(30 \mu \mathrm{g})$. The susceptibilites to other antibiotics that differentiate the two strains are shown in Table 1.

Fatty acids of whole cells of strain $\mathrm{W} 3-3 \mathrm{~A}^{\mathrm{T}}$ and $B$. denitrificans $\mathrm{BD}^{\mathrm{T}}$ grown on $216 \mathrm{~L}$ plate medium $\left(1^{-1}\right.$ seawater: peptone, $10 \mathrm{~g}$; yeast, $2 \mathrm{~g}$; sodium acetate, $1 \mathrm{~g}$; citrate, $0.5 \mathrm{~g}$; agar, $15 \mathrm{~g} ; \mathrm{pH} 7.5$ ) at $28{ }^{\circ} \mathrm{C}$ for $48 \mathrm{~h}$ were extracted, saponified and esterified. Analysis of the fatty acid methyl esters was performed using GC, according to the instructions of the MIDI system (Sasser, 1997). The fatty acid profile of $B$. denitrificans $\mathrm{BD} 1^{\mathrm{T}}$ was determined in parallel with strain $\mathrm{W} 3-3 \mathrm{~A}^{\mathrm{T}}$. The fatty acid profiles of the two strains are shown in Supplementary Table S1 (in

Table 1. Differential physiological characteristics of strain W3-3A $\mathrm{A}^{\top}$ (B. pacifica sp. nov.) and B. denitrificans $\mathrm{BD} 1^{\top}$

Data for B. denitrificans $\mathrm{BD}^{\mathrm{T}}$ were taken from Jean et al. (2006). Characteristics are scored as: $\mathrm{W}$, weakly positive; + , positive; - , negative.

\begin{tabular}{|c|c|c|}
\hline Characteristic & $\begin{array}{c}\text { Strain } \\
\mathrm{W} 3-3 A^{T}\end{array}$ & $\begin{array}{l}\text { Strain } \\
\mathrm{BD1}^{\mathrm{T}}\end{array}$ \\
\hline \multicolumn{3}{|l|}{ API $20 \mathrm{NE}^{*}$} \\
\hline$N$-Acetyl-glucosamine, maltose & - & + \\
\hline \multicolumn{3}{|l|}{ Susceptibility to antimicrobial agents ${ }^{\star}$} \\
\hline Furazolidone $(15 \mu \mathrm{g})$ & + & - \\
\hline $\begin{array}{l}\text { Kanamycin }(30 \mu \mathrm{g}) \text {, neomycin }(10 \mu \mathrm{g}) \text {, } \\
\text { ofloxacin }(5 \mu \mathrm{g}) \text {, piperacillin }(100 \mu \mathrm{g}) \text {, } \\
\text { streptomycin }(10 \mu \mathrm{g}) \text {, vancomycin } \\
(30 \mu \mathrm{g})\end{array}$ & - & + \\
\hline Growth in $10 \% \mathrm{NaCl}^{*}$ & + & $\mathrm{w}$ \\
\hline \multicolumn{3}{|l|}{ Utilization of: } \\
\hline D-Galactose & - & + \\
\hline Melibiose & + & - \\
\hline DNA G $+C$ content $(\mathrm{mol} \%)$ & 49 & 50 \\
\hline
\end{tabular}

${ }^{*}$ The characteristics of strain $\mathrm{BD}^{\mathrm{T}}$ were determined in this study at the same time as strain $\mathrm{W} 3-3 \mathrm{~A}^{\mathrm{T}}$.
IJSEM Online). The major fatty acids of the two strains were $\mathrm{C}_{16: 1} \omega 7 c / \omega 6 c(30.4 \%), \mathrm{C}_{16: 0}(23.3 \%), \mathrm{C}_{17: 1} \omega 8 c$ $(7.1 \%)$ and $\mathrm{C}_{18: 1} \omega 7 c(13.8 \%)$, accounting for $>74 \%$ of the total fatty acids. The amounts of summed feature 3 $\left(\mathrm{C}_{16: 1} \omega 7 c / \omega 6 c\right)$ of the two strains were different. Strain $\mathrm{W} 3-3 \mathrm{~A}^{\mathrm{T}}$ has one peak corresponding to summed feature 3 , which accounted for the content of $30.4 \%$. However, $B$. denitrificans $\mathrm{BD}^{\mathrm{T}}$ had two close peaks that corresponded to summed feature 3, which accounted for 27.7 and $6.7 \%$, respectively. As the fatty acid profiles of strain $\mathrm{W} 3-3 \mathrm{~A}^{\mathrm{T}}$ and $B$. denitrificans $\mathrm{BD}^{\mathrm{T}}$ were determined under the same conditions, strain W3-3 $\mathrm{A}^{\mathrm{T}}$ could be distinguished from $B$. denitrificans $\mathrm{BD} 1^{\mathrm{T}}$ based on the differences in proportion.

Polar lipids of strain $\mathrm{W} 3-3 \mathrm{~A}^{\mathrm{T}}$ and $B$. denitrificans $\mathrm{BD} 1^{\mathrm{T}}$ were extracted and separated according to the methods described by Tindall (1990). The results are shown in Supplementary Fig. S5 (in IJSEM Online). The major polar lipids of strain $\mathrm{W} 3-3 \mathrm{~A}^{\mathrm{T}}$ and $B$. denitrificans $\mathrm{BD}^{\mathrm{T}}$ were an unidentified aminolipid, diphosphatidglycerol, phosphatidylglycerol and phosphatidylethanolamine. Minor amounts of phosphatidylinositol and an unidentified lipid were also detected in both strains. In the study of Jean et al. (2006), only phosphatidylglycerol and phosphatidylethanolamine were detected.

The G+C content of the chromosomal DNA was determined according to the methods described by Mesbah \& Whitman (1989), using a reversed-phase HPLC. The DNA G $+\mathrm{C}$ content of strain $\mathrm{W} 3-3 \mathrm{~A}^{\mathrm{T}}$ was $49 \mathrm{~mol} \%$, similar to that of $B$. denitrificans $\mathrm{BD}^{\mathrm{T}}$.

The high level of $16 \mathrm{~S}$ rRNA gene similarity between strain W3-3 $\mathrm{A}^{\mathrm{T}}$ and $B$. denitrificans $\mathrm{BD} 1^{\mathrm{T}}$ confirmed that strain $\mathrm{W} 3-3 \mathrm{~A}^{\mathrm{T}}$ belonged to the genus Bowmanella. However, strain $\mathrm{W} 3-3 \mathrm{~A}^{\mathrm{T}}$ could be differentiated from $B$. denitrificans $\mathrm{BD} 1^{\mathrm{T}}$ based on data from the $g y r B$ and $r p o D$ gene sequence comparisons, DNA-DNA hybridization and rep-PCR fingerprints. On the basis of the data described above, strain $\mathrm{W} 3-3 \mathrm{~A}^{\mathrm{T}}$ should be placed in a novel species of the genus Bowmanella, for which the name Bowmanella pacifica sp. nov. is proposed.

\section{Emended description of the genus Bowmanella Jean et al. 2006}

Major polar lipids are an unidentified aminolipid, diphosphatidglycerol, phosphatidylglycerol and phosphatidylethanolamine. Minor amounts of phosphatidylinositol and an unidentified lipid are also detected.

\section{Description of Bowmanella pacifica sp. nov.}

Bowmanella pacifica (pa.ci'fi.ca. L. fem. adj. pacificus peaceful, pertaining to the Pacific Ocean).

Cells are rod-shaped, $0.6-0.8 \mu \mathrm{m}$ wide and $1.1-1.3 \mu \mathrm{m}$ long, and motile by means of a single polar flagellum. Positive for oxidase, catalase, gelatinase, $\beta$-glucosidase (aesculin hydrolysis) and $\beta$-galactosidase, but negative for 
Gram reaction, indole production, urease and arginine dihydrolase. On M2 agar medium, produces smooth greywhite colonies with regular edges that are $2-3 \mathrm{~mm}$ in diameter after $72 \mathrm{~h}$ incubation at $28{ }^{\circ} \mathrm{C}$, non-pigmented and slightly raised in the centre. Moderately halophilic; grows in $0-10 \% \mathrm{NaCl}$ (optimum, $0.5-7 \%$ ) and at 10 $42{ }^{\circ} \mathrm{C}$ (optimum, $25-37{ }^{\circ} \mathrm{C}$ ), but not at 4 or $45{ }^{\circ} \mathrm{C}$. Growth occurs at $\mathrm{pH}$ 6-10 (optimum, $\mathrm{pH}$ 8). Capable of denitrification; does not ferment glucose. Principal fatty acids are $\mathrm{C}_{16: 1} \omega 7 c / \omega 6 c, \mathrm{C}_{16: 0}, \mathrm{C}_{17: 1} \omega 8 c$ and $\mathrm{C}_{18: 1} \omega 7 c$. Among the 95 carbon sources in the Biolog GN2 system, positive reactions were obtained for utilization of acetic acid, trehalose, gentiobiose, glycyl L-aspartic acid, inosine, lactulose, L-alanine, L-proline, sucrose, turanose, $\alpha$-Dlactose, cellobiose, dextrin, D-fructose, D-mannose, melibiose, glycogen, glycyl L-glutamic acid, L-alaninamide, Lalanyl glycine, L-asparagine, L-glutamic acid, L-leucine, maltose, $\mathrm{N}$-acetyl-D-glucosamine, Tween 40 , Tween $80, \alpha-$ cyclodextrin, $\alpha$-D-glucose, $\beta$-hydroxybutyric acid and methyl $\beta$-D-glucoside. With API ZYM, positive for acid phosphatase, alkaline phosphatase, esterase lipase (C8), leucine aminopeptidase, $N$-acetyl- $\beta$-glucosaminidase, naphthol-AS-BI-phosphoamidase and valine aminopeptidase; weakly positive for cystine aminopeptidase, esterase (C4), trypsin and $\alpha$-chymotrypsin; and negative for lipase (C14), $\alpha$-fucosidase, $\alpha$-galactosidase, $\alpha$-glucosidase, $\alpha$ mannosidase, $\beta$-galactosidase, $\beta$-glucosidase and $\beta$-glucuronidase. Sensitive to chloramphenicol $(30 \mu \mathrm{g})$, ciprofloxacin $(5 \mu \mathrm{g})$, co-trimoxazole $(25 \mu \mathrm{g})$, erythromycin $(15 \mu \mathrm{g})$, furazolidone $(15 \mu \mathrm{g})$, gentamicin $(10 \mu \mathrm{g})$, norfloxacin $(10 \mu \mathrm{g})$, polymyxin $\mathrm{B}(30 \mathrm{IU})$ and rifampicin $(5 \mu \mathrm{g})$; resistant to ampicillin $(10 \mu \mathrm{g})$, carbenicillin $(100 \mu \mathrm{g})$, cefalexin $(30 \mu \mathrm{g})$, cefazolin $(30 \mu \mathrm{g})$, cefoperazone $(30 \mu \mathrm{g})$, cephradin $(30 \mu \mathrm{g})$, clindamycin $(2 \mu \mathrm{g})$, kanamycin $(30 \mu \mathrm{g})$, lincomycin $(2 \mu \mathrm{g})$, metronidazole $(5 \mu \mathrm{g})$, minocycline $(30 \mu \mathrm{g})$, neomycin $(10 \mu \mathrm{g})$, ofloxacin $(5 \mu \mathrm{g})$, oxacillin $(1 \mu \mathrm{g})$, penicillin $\mathrm{G}(10 \mu \mathrm{g})$, piperacillin $(100 \mu \mathrm{g})$, ceftriaxone $(30 \mu \mathrm{g})$, streptomycin $(10 \mu \mathrm{g})$, tetracycline $(30 \mu \mathrm{g})$, vancomycin $(30 \mu \mathrm{g})$ and doxycycline $(30 \mu \mathrm{g})$. The $\mathrm{G}+\mathrm{C}$ content of the DNA of the type strain is $49 \mathrm{~mol} \%$. Characteristics used to distinguish strain $\mathrm{W} 3-3 \mathrm{~A}^{\mathrm{T}}$ from $B$. denitrificans $\mathrm{BD} 1^{\mathrm{T}}$ are given in Table 1 .

The type strain, W3-3A $\mathrm{A}^{\mathrm{T}} \quad\left(=\mathrm{CGMCC} \quad 1.7086^{\mathrm{T}}=\mathrm{LMG}\right.$ $24568^{\mathrm{T}}=$ MCCC $1 \mathrm{~A} 01018^{\mathrm{T}}$ ), was isolated from marine sediment samples collected in 2002 from the Pacific Ocean.

\section{Acknowledgements}

This work was supported financially by the National Natural Science Foundation of China (40376041), National Infrastructure of Natural Resources for Science and Technology Program of China (no. 2005DKA21209), COMRA program (no. DYXM115-02-2-05) and the National Basic Research Program of China (no. 2004CB719601 and 2006CB708200). J. Y. is a PhD student of Xiamen University, cosupervised by T.Z. and Z.S.; the work was all performed in the Third Institute of Oceanography, State Oceanic Administration.

\section{References}

Ausubel, F. M., Brent, R., Kingston, R. E., Moore, D. D., Seidman, J. G., Smith, J. A. \& Struhl, K. (editors) (1995). Short Protocols in Molecular Biology: a Compendium of Methods from Current Protocols in Molecular Biology, 3rd edn. New York: Wiley.

Dong, X.-Z. \& Cai, M.-Y. (2001). Determinative Manual for Routine Bacteriology. Beijing: Scientific Press (English translation).

Ivanova, E. P., Kiprianova, E. A., Mikhailov, V. V., Levanova, G. F., Garagulya, A. D., Gorshkova, N. M., Vysotskii, M. V., Nicolau, D. V., Yumoto, N. \& other authors (1998). Phenotypic diversity of Pseudoalteromonas citrea from different marine habitats and emendation of the description. Int J Syst Bacteriol 48, 247-256.

Jean, W. D., Chen, J.-S., Lin, Y.-T. \& Shieh, W. Y. (2006). Bowmanella denitrificans gen. nov., sp. nov., a denitrifying bacterium isolated from seawater from An-Ping Harbour, Taiwan. Int J Syst Evol Microbiol 56, 2463-2467.

Liu, C. L. \& Shao, Z. Z. (2005). Alcanivorax dieselolei sp. nov., a novel alkane-degrading bacterium isolated from sea water and deep-sea sediment. Int J Syst Evol Microbiol 55, 1181-1186.

Mesbah, M. \& Whitman, W. B. (1989). Measurement of deoxyguanosine/thymidine ratios in complex mixtures by high-performance liquid chromatography for determination of the mole percentage guanine + cytosine of DNA. J Chromatogr 479, 297-306.

Rzhetsky, A. \& Nei, M. (1992). A simple method for estimating and testing minimum evolution trees. Mol Biol Evol 9, 945-967.

Rzhetsky, A. \& Nei, M. (1993). Theoretical foundation of the minimum-evolution method of phylogenetic inference. Mol Biol Evol 10, 1073-1095.

Saitou, N. \& Nei, M. (1987). The neighbor-joining method: a new method for reconstructing phylogenetic trees. Mol Biol Evol 4, 406425.

Sasser, M. (1997). Identification of bacteria by gas chromatography of cellular fatty acids, MIDI Technical Note 101. Newark, DE: MIDI Inc.

Shieh, W. Y., Chen, Y.-W., Chaw, S.-M. \& Chiu, H.-H. (2003). Vibrio ruber sp. nov., a red, facultatively anaerobic, marine bacterium isolated from sea water. Int J Syst Evol Microbiol 53, 479-484.

Tamura, K., Dudley, J., Nei, M. \& Kumar, S. (2007). MEGA4: Molecular Evolutionary Genetics Analysis (MEGA) software version 4.0. Mol Biol Evol 24, 1596-1599.

Tindall, B. J. (1990). Lipid composition of Halobacterium lacusprofundi. FEMS Microbiol Lett 66, 199-202.

Versalovic, J., Koeuth, T. \& Lupski, J. R. (1991). Distribution of repetitive DNA sequences in eubacteria and application to fingerprinting of bacterial genomes. Nucleic Acids Res 19, 6823-6831.

Wang, B. J., Lai, Q. L., Cui, Z. S., Tan, T. F. \& Shao, Z. Z. (2008). A pyrene-degrading consortium from deep-sea sediment of the west pacific and its key member Cycloclasticus sp. P1. Environ Microbiol 10, 1948-1963.

Wayne, L. G., Brenner, D. J., Colwell, R. R., Grimont, P. A. D., Kandler, O., Krichevsky, M. I., Moore, L. H., Moore, W. E. C., Murray, R. G. E. \& other authors (1987). International Committee on Systematic Bacteriology. Report of the ad hoc committee on reconciliation of approaches to bacterial systematics. Int J Syst Bacteriol 37, 463-464.

Yamamoto, S., Kasai, H., Arnold, D. L., Jackson, R. W., Vivian, A. \& Harayama, S. (2000). Phylogeny of the genus Pseudomonas: intrageneric structure reconstructed from the nucleotide sequences of gyrB and rpoD genes. Microbiology 146, 2385-2394. 